\title{
TINJAUAN FIKIH MUAMALAH TERHADAP AKAD JUAL BELI DALAM TRANSAKSI ONLINE PADA APLIKASI GO-FOOD
}

\author{
${ }^{1}$ Muhammad Yunus, ${ }^{2}$ Fahmi Fatwa Rosyadi Satria Hamdani, ${ }^{3}$ Gusti Khairina Shofia \\ ${ }^{1,2,3,}$ FakultasSyariah, Universitas Islam Bandung, Jl. Ranggagading No. 8 Bandung 40116 \\ email :lfatwa19@gmail.co.id
}

\begin{abstract}
Abstrak : Transaksi jual beli dalam Islam semakin berkembang seiring dengan semakin berkembangnya zaman dan teknologi. Hal ini tentunya menjadi tantangan bagi umat muslim untuk dapat lebih menelaah lebih jauh terhadap transaksi-transaksi yang sedang berkembang, salah satunya layanan go-food pada aplikasi go-jek. Apakah akad-akad dari pihak-pihak yang terkait sudah sesuai dengan syariat atau sebaliknya. Oleh karenanya penelitian ini bermaksud untuk mengetahui jenis-jenis akad yang terdapat dalam layanan go-food dalam aplikasi gojek, serta pandangan Islam terhadap akad-akad tersebut. Penelitian ini menggunakan pendekatan kualitatis dengan analisis konsep, di mana peneliti mengumpulkan sumbersumber bacaan yang memiliki keterkaitan dengan bahasan yang sedang dikaji. Hasil dari penelitian ini, dijumpai bahwa akad sewa menyewa terjadi antara perusahaan go-jek dengan penyedia layanan / pengemudi ojek, antara perusahaan go-jek dengan penjual yang terdaftar dalam layanan go-food, dan antara perusahan go-jek dengan pengguna layanan. Akad jual beli terjadi antara pengguna layanan go-food dengan penjual makanan, dan antara penyedia layanan / pengemudi ojek dengan penjual yang terdaftar dalam layanan go-food. Sedangkan akad wakalah terjadi antara pengguna layanan go-food dengan penyedia layanan / pengemudi ojek. Adapun transaksi-transaksi yang dilakukan tersebut dapat diketahui telah sesuai dengan rukun dan syaratnya.
\end{abstract}

Kata Kunci: Jual Beli, Go-jek, Go-food

Abstract : Transactions in buying and selling in Islam are growing along with the growing era and technology. This is certainly a challenge for Muslims to be able to further explore the growing transactions, blame go-food services on go-jek applications. Are the contracts of the parties concerned are in accordance with the Shari'a or vice versa. By completeness of this study for the types of contracts that exist in go-food services in go-jek applications, as well as Islamic views of these contracts. This study uses a qualitative approach to the concept, in which researchers a collection of reading sources that have relevance to the subject under study. The results of this study found lease agreements with businesses between go-jek companies and ojek service providers, between go-jek companies and sellers who subscribe to food services, and between go-jek companies and service users. Buy and sell agreements occur between food and beverage with food service, and between ojek service providers / drivers with sellers who subscribe to go-food services. While akad wakalah occurs between users of go-food services with service providers / motorcycle drivers. As these transactions can be known already in accordance with the rules and conditions.

Keywords: Sell Buy, Go-Jek, Go-food

Received: 2018-01-07| Reviced: 2018-01-30| Accepted: 2018-01-31

Indexed : DOAJ, Garuda, Crossref, Google Scholar | DOI : https://doi.org/10.29313/amwaluna.v2i1.3363 


\section{PENDAHULUAN}

\section{Latar Belakang}

Dewasa ini perkembangan teknologi semakin memanjakan masyariatat dalam mempermudah berbagai aktifitas sehari-hari. Aktifitas yang dahulu terkesan membuang banyak waktu dan biaya, kini dapat dinikmati dengan lebih mudah dan praktis tanpa merasa kerepotan. Salah satunya dengan fasilitas layanan online yang masyariatat nikmati sekarang.

Berbagai macam fasilitas layanan online yang tersedia di masyariatat, mulai dari sarana pembayaran online, belanja online, hingga transportasi online dengan mudah dapat dinikmati melalui sarana ecommerce yang banyak tersedia saat ini. Salah satu fasilitas layanan jasa tranportasi online yang paling populer di masyariatat yaitu aplikasi Gojek.

Gojek merupakan aplikasi yang menawarkan layanan jasa transportasi online dengan menyediakan berbagai fasilitas lainnya yang kesemuanya menawarkan layanan dibidang jasa. Layanan yang paling diminati setelah transportasi kendaraan beroda dua dan empat dalam aplikasi gojek ini adalah layanan Go-food, di mana para pelanggan dapat menggunakan layanan jasa pesan antar makanan, sesuai dengan kebutuhan atau minat customer.
Ketika driver gojek mendapatkan order dari pelanggan atas pemesanan makanan, maka pihak driver gojek memberikan dana talangan terlebih dahulu yang kemudian akan diganti oleh pelanggan setelah pesanannya telah diantarkan. Sebagai seorang muslim, maka perlu dilakukan kajian untuk berfikir kritis terhadap berbagai fenomena baru atau sesuatu yang sedang berkembang di masyariatat. Apakah fenomena tersebut masih sesuai dengan ajaran dan kaidah syariah atau sudah keluar dari kaidah yang seharusnya. Dalam kaidah ushul fiqh, hukum dasar mu'amalah adalah boleh kecuali terdapat dalil yang melarangnya. Berdasarkan uraian tersebut, maka peneliti melakukan pembahasan tinjauan akad jual beli yang terjadi pada aplikasi go-food. Selain itu pun dilakukan pembahasan tentang pandangan hukum Islam terhadap transaksi berbasis online (go-food) tersebut.

\section{Tujuan Penelitian}

a. Untuk mengetahui model akad yang diterapkan oleh para pihak yang terkait, seperti perusahaan gojek, sdm yang bekerja pada perusahaan gojek, penjual, dan pembeli (customer) pada layanan aplikasi go-food. 
b. Untuk mengetahui pandangan hukum Islam terhadap transaksi berbasis online (go-food) tersebut.

\section{Metode Penelitian}

Penelitian ini menggunakan pendekatan kualitatif dalam bentuk yuridis normatif. Metode yang digunakan berupa analisis konsep. Penelitian dilakukan dengan mencari sumber-sumber rujukan yang relevan dengan kajian yang akan diteliti, seperti dari jurnal terbaru, buku, majalah, dan bahan rujukan lainnya. Setelah terkumpul bahan-bahan yang akan dimasukkan ke dalam kajian, maka selanjutnya pemakalah menganalisis konsep tersebut untuk selanjutnya mengambil beberapa simpulan dari rumusan masalah yang telah ditentukan di awal.

\section{Kerangka Teori}

\section{Akad dan Jual Beli dalam Islam}

Istilah akad berasal dari bahasa Arab, yaitu al-'aqdu yang berarti perjanjian yang tercatat atau kontrak. ${ }^{1}$ Sayyid Sabiq dalam kitabnya fikih sunah memberikan arti bahwa akad adalah suatu ikatan dan kesepakatan. ${ }^{2}$ Adapun sumber lain ada yang mengartikan bahwa akad

\footnotetext{
${ }^{1}$ Ahmad Warson Munawwir, Kamus al-Munawwir Arab-Indonesia lengkap, Surabaya: Pustaka Progresif, 1997, hal. 953.

${ }^{2}$ Sayyid Sabiq, Fikih Sunnah Juz. 3. , Beirut: Darul Fikri, 1995. hal 93.
}

Online ISSN : 2540-8402 | Print ISSN : 2540-8399 sebagai pertalian ijab dan kabul sesuai dengan kehendak syariat yang berpengaruh pada suatu objek perikatan. ${ }^{3}$ Ijab adalah suatu pernyataan seseorang yang melakukan ikatan, sedangkan kabul diidentikkan sebagai suatu pernyataan penerimaan terhadap ikatan tersebut. Dalam Islam, tentunya seluruh perikatan yang dilakukan oleh dua pihak ataupun lebih, harus sesuai dengan kehendak syariat.

Berkaitan dengan akad, Mustafa Ahmad az-Zarqa sebagaimana yang dijelaskan dalam ensikolpedi hukum islam, membedakan dua macam tindakan hukum yang dilakukan oleh seseorang, di antaranya: ${ }^{4}$

1. Tindakan yang berupa perkataan:

a. Bersifat akad: terjadi apabila dua atau beberapa pihak mengikatkan diri untuk melakukan suatu perjanjian. Misalnya seorang penjual di sebuah pasar yang menyatakan bahwa ia telah menjual barangnya dengan harga "sekian" dan pihak lainnya/pembeli menyatakan bahwa ia membeli barang tersebut dengan harga yang telah ditetapkan penjual

\footnotetext{
3 Abdul Aziz Dahlan dkk, Ensiklopedi Hukum Islam, Jakarta: Ichtiar Baru Van Hoeve, 2001, jilid 1 hal. 63. Lihat juga Eka Nuraini Rachmawati dan Ab Mumin bin Ab Ghani, Akad Jual Beli dalam Perspektif Fikih dan Praktiknya di Pasar Modal Indonesia, Jurnal al-'Adalah, Vol. 12 (4). hal. 786 (785-806).

${ }^{4}$ Ibid.
} 
tersebut. Tindakan yang serperti inilah yang bersifat akad, karena antara pihak penjual dan pembeli telah mengikatkan diri untuk melakukan suatu perbuatan jual dan beli.

b. Tidak bersifat akad:

1) Yang mengandung kehendak pemilik untuk menetapkan atau melimpahkan hak, membatalkannya, atau menggugurkannya, contoh: wakaf, hibah, dan talak. Akad dengan perbuatan seperti ini tidak memerlukan kabul, walaupu beberapa ulama masih berbeda pendapat terkait tindakan hukum tersebut. Ada yang berpendapat telah terjadi akad dan ada pula sebaliknya, tidak terjadi akad.

2) Yang tidak mengandung kehendak pihak yang menetapkan atau menggugurkan suatu hak, akan tetapi perkataannya memunculkan suatu tindakan hukum. Salah satu contohnya adalah gugatan yang diajukan kepada hakim dan pengakuan seseorang di depan hakim. Tindakan demikian akan menimbulkan suatu ikatan secara hukum, namun sifatnya tidak mengikat.
2. Tindakan yang berupa perbuatan. ${ }^{5}$

Adapun jual beli dalam masyariatat saat ini, merupakan rutinitas harian yang biasa dilakukan antara dua pihak atau lebih. Bahkan hal tersebut telah diatur dalam al-Qur'an dan hadis. Namun jual beli yang sesuai menurut syariat belum tentu semua masyariatat muslim melakukannya, atau mungkin tidak ada yang mengetahui sama sekali tentang ketentuan-ketentuan dalam praktek jual beli. ${ }^{6}$

Untuk mendapatkan definisi yang lebih jelas terhadap jual beli (al-bai'u), pemakalah menemukan beberapa sumber yang memberikan pengertian terkait jual beli, seperti yang dikemukakan oleh Taqiyyuddin, ${ }^{7}$ Zainuddin, ${ }^{8}$ Dimyauddin, ${ }^{9}$ dan Sabiq, ${ }^{10}$ bahwa jual beli merupakan suatu kegiatan pertukaran barang dengan barang, atau harta dengan harta, yang dilakukan oleh pembeli dan penjual

5 Sebagai bahan tambahan, Zarqa menjelaskan lebih lanjut bahwa setiap akad yang dilakukan seseorang atau badan hukum dapat dikatakan sebagai tindakan hukum dari dua atau beberapa pihak, akan tetapi sebaliknya bahwa setiap tindakan hukum tidak dapat disebut sebagai akad. Ibid.

6 Shobirin, Jual Beli dalam Pandangan Islam, Jurnal Bisnis dan Manajemen Islam, Vol. 3 (2), 2015, hal. 240.

7 Taqiyuddin Abu Bakar bin Muhammad al-Husna, Kifayatu al-Akhyar fi Halli Ghayat al-ikhtishar fi al-Fiqh asy-Syafi'i, Damaskus: Dar al-Basyair, 2001, hal. 279.

8 Ahmad Zainuddin bin Abdul Aziz, Fathu alMu'in, Beirut: Dar Ibn Hazm, 2004, hal. 316-317.

${ }^{9}$ Dimyaudin Djuwaini, Pengantar Fiqh Muamalah, Yogyakarta: Pustaka Pelajar 2008, hal. 69.

${ }^{10}$ Sayyid Sabiq, Fiqh Sunnah, Jilid 3, Beirut: Darul Fikri, 1995, hal. 92-93. 
dengan sighat, yaitu ungkapan ijab dan kabul, dilakukan dengan sukarela antara masing-masing pihak, dan harta yang ditukar adalah yang bernilai manfaat.

\section{Rukun, Syarat, dan Dasar Hukum Jual Beli}

Jual beli dalam istilah fiqh disebut dengan al-bai'u yang berarti menjual, mengganti, dan menukar sesuatu dengan sesuatu yang lain. Dalam definisi menurut ulama hanafiyah jual beli ialah "Tukar menukar sesuatu yang diingini dengan yang sepadan melalui cara tertentu yang bermanfaat". yang dimaksud ialah melalui ijab dan qabul (pernyataan menjual dari penjual), atau juga boleh melalui saling memberikan barang dan harga dari penjual dan pembeli. disamping harta yang diperjual belikan harus bermanfaat bagi manusia. ${ }^{11}$ Objek jual beli bukanlah objek yang dilarang dan harus sesuai kaidah syari'ah. sebagaimana yang dijelaskan dalam sebuah hadist:

$$
\begin{aligned}
& \text { إِنَّ اللَّهَ وَرَسُولَهُ حَرَّمَ بَيْعَ الخْنْمرِ وَالْمَيْتَةِ } \\
& \text { وَالْنْنْيِرِ وَاَلأَصْنَام }
\end{aligned}
$$

“ Sesungguhnya Allah dan Rasul-Nya mengharamkan jual beli khamr, bangkai, babi dan patung" (Muttafaq 'alaih).

${ }^{11}$ Hasrun Haroen, Fiqh Muamalah (Jakarta: Gaya Media Pratama, hal. 111-112

Online ISSN : 2540-8402 | Print ISSN : 2540-8399
Dasar hukum jual beli ialah ijma', yaitu karena manusia sebagai anggota masyariatat selalu membutuhkan apa yang dihasilkan dan dimiliki oleh orang lain. ${ }^{12}$ Oleh karena itu, jual beli adalah salah satu jalan untuk mendapatkan suatu objek secara sah. Berdasarkan hal tersebut, maka mudahlah bagi setiap individu memenuhi kebutuhannya. Ekonomi Islam berdiri di atas prinsip perdagangan yang berdasarkan syari'at, yaitu dengan mengembangkan harta melalui cara-cara yang dihalalkan oleh Allah SWT, sesuai dengan kaidahkaidah dan ketentuan-ketentuan muamalah syar'iyyah, yang didasarkan pada hukum pokok (boleh dan halal dalam berbagai mu'amalat) dan menjauhi segala yang diharamkan oleh Allah Ta'ala, misalnya, riba. Allah Ta'ala berfirman:

\section{"Allah telah menghalalkan} jual beli dan mengharamkan riba. "(QS. Al-Baqarah: 275)

Di dalam transaksi jual beli harus terpenuhi rukun dan syaratnya. Rukun jual beli adalah sesuatu yang harus ada
12 Ahmad bin Abdurrazzaq ad-Duwaisy, Fatwafatwa Jual Beli, Jakarta: Pustaka Imam asy-Syafi'i, hal. 2. 
dalam setiap perbuatan hukum. Rukun jual beli tersebut terdapat tiga macam: ${ }^{13}$

a. Ijab kabul (akad), yaitu ikatan kata antara penjual dan pembeli, syarat kabul antara lain:

1) jangan ada tenggang waktu yang memisahkan antara ucapan penjual dan pembeli.

2) jangan diselangi kata-kata lain antara penjual dan pembeli.

b. orang-orang yang berakad, penjual dan pembeli; dan

c. objek akad (ma'qud alaih).

Adapun syarat jual beli dibagi menjadi dua, yaitu syarat untuk objek jual beli dan syarat untuk orang yang melakukan transaksi jual beli. Adapun syarat untuk objeknya, di antaranya: ${ }^{14}$

a. suci dan bisa disucikan.

b. bermanfaat menurut hukum islam.

c. tidak digantungkan pada suatu kondisi tertentu.

d. tidak dibatasi tenggang waktu tertentu.

e. dapat diserahkan.

f. milik sendiri.

g. tertentu atau dapat diindra.
Ulama fikih telah menetapkan beberapa syarat umum yang harus dipenuhi dalam suatu akad yaitu: ${ }^{15}$

a. Pihak-pihak yang melakukan akad telah cakap untuk bertidak hukum/mukallaf, atau apabila obyek akad merupakan kepunyaan orang yang tidak atau belum cakap bertindak hukum, maka yang berhak bertindak adalah walinya.

b. Objek akad tersebut diakui oleh syariat. Benda yang menjadi objek adalah bukan barang najis, akan tetapi bermanfaat, bisa diserah terimakan, kepunyaan orang yang menjualnya atau orang yang menjualnya dikuasakan untuk menjualnya.

c. Akad tersebut tidak dilarang oleh nas syariat.

d. Akad yang dilakukan memenui syarat-syarat khusus.

e. Akad itu bermanfaat.

f. Ijab tetap utuh dan shahih sampai terjadinya kabul.

g. Ijab dan kabul dilakukan dalam satu majlis, yaitu suatu keadaan yang menggambarkan suatu transaksi.

h. Tujuan akad jelas dan diakui oleh syariat.

15 Abdul Aziz Dahlan, ....., ibid, hal. 65-67. Lihat juga Abd. Shomad, Hukum Islam: Penormaan Prinsip Syariah dalam Hukum Indonesia, Bandung: Kencana, 2017, hal. 155-156.
${ }^{13}$ Sayyid Sabiq, ....., Ibid, hal. 93. Lihat juga Hendi suhendi. Fiqh mualmalah, Jakarta: PT. Raja Grafindo Persada, hal. 70.

14 Ibid.

Online ISSN : 2540-8402 | Print ISSN : 2540-8399 
Macam-Macam Akad dan Jual Beli dalam Islam

Kontrak jual beli menjadi sempurna (tamn) dengan terjadinya penyerahan barang (taqabud). Pengakuan untung atau rugi dari salah satu pihak yang tidak berkenan dengan tujuan kontrak (misalkan bahwa pembeli harus membebaskan budak yang dia beli) adalah tidak sah dan itu berarti membuat kontrak menjadi cacat. ${ }^{16}$

Suatu akad dalam Islam dibagi menjadi beberapa macam, yaitu dari segi keabsahannya menurut syariat dan dari segi penamaannya. ${ }^{17}$ Dari segi keabsahannya menurut syariat, dibagi menjadi dua:

1. Akad shahih, yaitu yang telah memenuhi rukun dan syaratnya. ${ }^{18}$

2. Akad yang tidak shahih, yang terdapat kekurangan pada rukun dan syaratnya.

16 Joseph Schacht, Pengantar Hukum Islam, Yogyakarta: Islamika, 2003.

17 Abdul Aziz Dahlan,...., Ibid, hal. 67-68. Lihat juga Siswadi, Jual Beli dalam Perspektif Islam, Jurnal Ummul Qura, Vol. 3 (2), hal. 63-65.

18 Para ulama mazhab Hanafi dan Maliki membagi akad shahih menjadi dua, yaitu (1) akad shahih yang nafiz (sempurna untuk dilaksanakan), yaitu akad yang dilangsungkan dengan memenuhi rukun dan syaratnya dan tidak ada penghalang untuk melakukannya, dan (2) akad shahih yang mauquf, yaitu akad yang dilakukan oleh seseorang yang cakap untuk bertindak hukum, namun ia tidak memiliki kekuasaan untuk melangsungkan dan melaksanakan akad tersebut, seperti akad yang dilakukan oleh anak kecil yang sudah mumayyiz, lebih lengkapnya lihat Abdul Aziz Dahlan, ...., hal. 67-68.

Online ISSN : 2540-8402 | Print ISSN : 2540-8399
Adapun dari segi penamaannya, dibagi menjadi dua:

1. Akad-akad yang namanya telah ditentukan sesuai syariat dan telah dijelaskan hukum-hukumnya, seperti jual beli, sewa menyewa, perserikatan, hibah, al-wakalah, wakaf, hiwalah, ji'alah, wasiat, dan perkawinan.

2. Akad-akad yang penamaannya ditentukan oleh masyarakat, sesuai dengan kebutuhan sepanjang zaman dan tempat, seperti istisna dan bai alwafa'.

Fikih muamalah, telah mengidentifikasi dan menguraikan macam-macam jual beli, termasuk jenisjenis jual beli yang dilarang oleh Islam. Macam atau jenis jual beli tersebut ialah:

a. Bai' al mutlaqah, yaitu pertukaran antara barang atau jasa dengan uang. Uang berperan sebagai alat tukar. Jual-beli semacam ini menjiwai semua produk-produk lembaga keuangan yang didasarkan atas prinsip jual-beli.

b. Bai' al muqayyadah, yaitu jual beli dimana pertukaran terjadi antara barang dengan barang (barter). Aplikasi jual beli semacam ini dapat dilakukan sebagai jalan keluar bagi transaksi ekspor yang tidak dapat 
menghasilkan valuta asing (devisa). karena itu dilakukan pertukaran barang dengan barang yang dinilai dalam valuta asing. Transaksi semacam ini lazim disebut Counter trade.

c. Bai' al sharf, yaitu jual-beli atau pertukaran antara satu mata uang asing dengan mata uang asing lain, seperti antara rupiah dengan dolar, dolar dengan yen dan sebagainya. Mata uang asing yang diperjualbelikan itu dapat berupa uang kartal (bank notes) ataupun bentuk uang giral (telegrafic transfer atau mail transfer).

d. Bai' al murabahah adalah akad jual beli barang tertentu. Dalam transaksi jual beli tersebut penjual menyebutkan dengan jelas barang yang diperjualbelikan, termasuk harga pembelian dan keuntungan yang diambil.

e. Bai' al musawamah adalah jual-beli biasa, dimana penjual tidak memberitahukan haga pokok dan keuntungan yang didapatnya.

f. Bai' al muwadha'ah yaitu jual beli dimana penjual melakukan penjualan dengan harga yang lebih rendah daripada harga pasar atau dengan potongan (discount). penjualan semacam ini biasanya hanya dilakukan untuk barangbarang atau aktiva tetap yang nilai bukunya sudah sangat rendah.

g. Bai' as salam adalah akad jual beli di mana pembeli membayar uang (sebesar harga) atas barang yang telah disebutkan spesifikasinya, sedangkan barang yang diperjualbelikan itu akan diserahkan kemudian, yaitu pada tanggal yang disepakati. Bai' as salam biasanya dilakukan untuk produk-produk pertanian jangka pendek.

h. Bai' al istishna' hampir sama dengan bai' as salam, yaitu kontrak jual-beli dimana harga atas barang tersebut dibayar lebih dulu tapi dapat diangsur sesuai dengan jadwal dan syarat-syarat yang disepakati bersama, sedangkan barang yang dibeli diproduksi dan diserahkan kemudian.

Di antara jenis-jenis jual beli tersebut, yang lazim digunakan dalam bertransaksi adalah yang berdasarkan prinsip bai' al murabahah, bai' as salam dan bai' al istishna'. ${ }^{19}$

\section{PEMBAHASAN}

\section{Gambaran Umum Layanan Go-Food pada Aplikasi Go-jek}

19 Zainul Arifin. Dasar-dasar Manajemen Bank Syariah, Jakarta: Pustaka Alfabet, 2012, hal. 26-27. 
Go-jek hadir pada tahun 2010 di Indonesia, yang merupakan perusahaan transportasi roda dua melalui panggilan telepon. Dikutip dari halaman resmi webnya, saat ini go-jek telah berkembang begitu pesat menjadi perusahaan teknologi yang menyediakan berbagai macam layanan yang berjiwa sosial. Maksud dan tujuannya tidak lain adalah untuk meningkatkan kesejahteraan pekerja di berbagai sektor informal di Indonesia. ${ }^{20}$

Beberapa layanan yang ditawarkan oleh go-jek kepada masyarakat sangat beraneka ragam, mulai dari transportasi roda dua, transportasi roda empat, layanan antar barang, pemesanan dan pembelian makanan, dan lain sebagainya. ${ }^{21}$ Tidak sedikit masyarakat dari berbagai macam latar belakang yang berbeda dan beragam usia, ikut menikmati layanan salah satu aplikasi online ini.

Pada setiap layanan yang ditawarkan oleh perusahaan go-jek kepada customer, tentunya mempunyai prosedur yang berbeda, sesuai dengan layananlayanan yang telah disediakan perusahaan, sebagaimana yang telah diatur pada kolom syarat dan ketentuan yang dibuat oleh

${ }^{20}$ Info terkait go-jek diakses langsung dari situs web https://www.go-jek.com/about/, diakses pada 7 Januari 2018 jam 16.30 WIB.

21 Berbagai macam layanan yang ditawarkan gojek, selengkapnya dapat diakses pada halaman web resminya https://www.go-jek.com/about/.

Online ISSN : 2540-8402 | Print ISSN : 2540-8399 perusahaan dan ini semua dapat dilihat di halaman resmi webnya.

Namun, pada makalah ini, pemakalah hanya akan fokus pada layanan go-food yang disediakan go-jek. Pada layanan ini, setidaknya dijumpai beberapa pihak, di antaranya perusahaan sebagai pihak pertama yang mempunyai aplikasi, kemudian customer atau pengguna aplikasi go-jek sebagai pihak kedua, pengemudi ojek atau para penyedia layanan kendaraan bermotor yang telah bekerjasama dengan perusahaan go-jek sebagai pihak ketiga, dan penjual makanan sebagai pihak keempat. Apabila ditelusuri lebih dalam lagi, maka akan dijumpai beberapa akad yang telah dilakukan oleh keempat pihak tersebut.

Ketika seseorang ingin memesan makanan dengan menggunakan layanan go-food pada aplikasi go-jek, maka setidaknya terdpat empat pihak yang terlibat dengan beberapa macam akad, di antaranya:

1. Akad sewa menyewa antara perusahaan go-jek dengan penyedia layanan / pengemudi ojek, antara perusahaan go-jek dengan penjual yang terdaftar dalam layanan gofood, dan antara perusahan go-jek dengan pengguna layanan.

2. Akad jual beli antara pengguna layanan go-food dengan penjual 
makanan, dan antara penyedia layanan / pengemudi ojek dengan penjual yang terdaftar dalam layanan go-food.
3. Akad wakalah antara pengguna layanan go-food dengan penyedia layanan / pengemudi ojek.

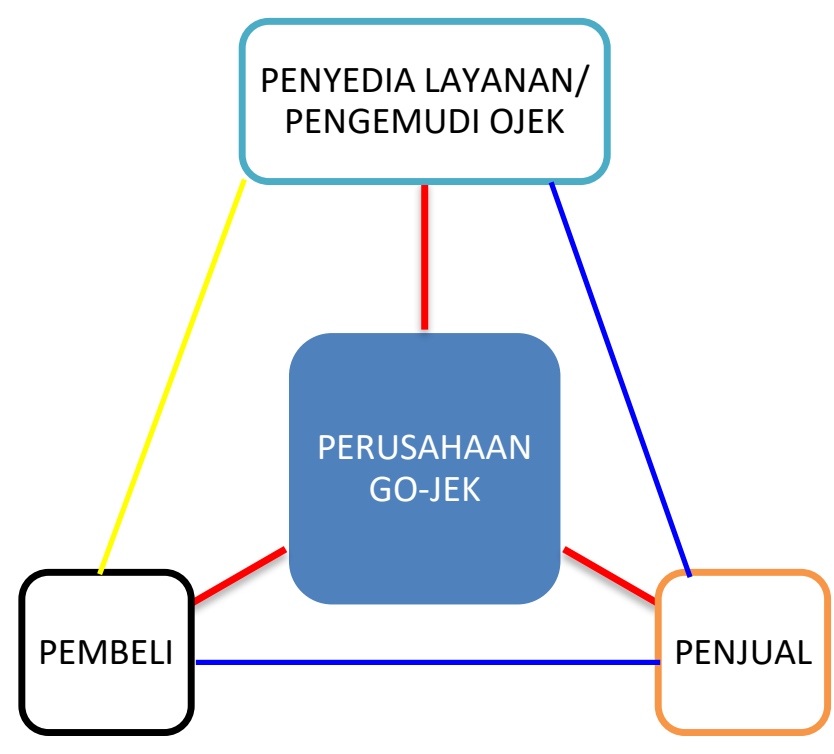

Keterangan:

Garis Merah: Akad Sewa Menyewa

Garis Biru: Akad Jual Beli

Garis Kuning: Akad Wakalah

Pihak pertama selaku perusahaan, tidak dapat menjalankan roda perusahaan tanpa adanya penyedia layanan atau pengemudi go-jek. Oleh karenanya, pihak perusahaan bekerja sama dengan pihak penyedia layanan dalam memberikan pelayanan sebaik mungkin kepada para customer go-jek. Akad yang dibuat pun cukup jelas, karena tercantum dalam syarat dan ketentuan yang diberikan kepada calon penyedia layanan pada saat mendaftar pertama kali untuk bermitra. Akad tersebut termasuk dalam kategori akad sewa menyewa, di mana pengemudi ojek menyewa aplikasi go-jek yang memuat berbagai macam layanan sosial masyarakat untuk mendapatkan pelanggan atau customer, yang dalam hal ini layanan go-food.

Setiap kali transaksi terjadi, pihak penyedia layanan / pengemudi ojek akan memberikan biaya sewa aplikasi dalam jumlah tertentu kepada perusahaan, dan biasanya pembayaran menggunakan jumlah persentase dari 
pendapatan setiap kali transaksi. Hal yang demikian pun terjadi antara perusahaan go-jek dengan penjual yang terdaftar dalam layanan go-food, namun tidak dengan pembeli. Dalam hal ini, meskipun pengguna layanan (pembeli) telah menyewa aplikasi dengan mengunduhnya di playstore, ia tidak dibebankan untuk membayar saat mengunduh, namun ada beberapa persyaratan yang perlu disepakati apabila ingin menggunakan aplikasi gojek, seperti penyantuman data pribadi agar dapat diakses oleh perusahaan sebagai data base pengguna aplikasi gojek.

Akad selanjutnya adalah akad jual beli, yang dalam hal ini terjadi antara pengguna layanan / pembeli dengan penjual, dan antara penyedia layanan / pengemudi ojek dengan penjual.

Akad yang terakhir adalah akad wakalah yang terjadi antara pengguna layanan / pembeli dengna penyedia layanan / pengemudi ojek, di mana penyedia layanan / pengemudi ojek menggantikan pembeli untuk melakukan transaksi jual beli langsung dengan penjual. Apabila transaksi berjalan dengan lancar, maka penyedia layanan / pengemudi ojek akan mendapatkan reward dalam bentuk bintang, yang nantinya menjadi penilaian terhadap kinerja keseharian dan berdampak kepada reward yang akan diterima dari perusahaan.

Dalam hal pemberian reward atau upah, Rasulullah SAW bersama Abu Bakar pernah mengupah seorang lakilaki dari Bani Diel sebagai petunjuk jalan yang pandai, dan hal ini diriwayatkan oleh Ahmad dan Bukhari: ${ }^{22}$
22 Faishal bin Abdul Aziz, Terjemahan Nailul Author (terjemahan oleh A. Qadir Hassan dkk), jilid 4, Surabaya, PT Bina Ilmu, hal 1861. 


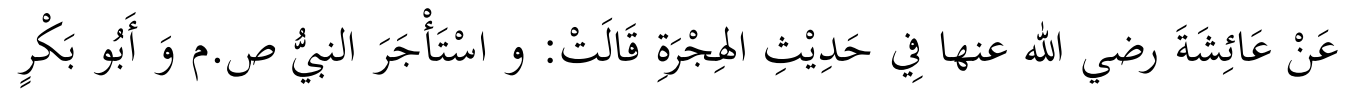

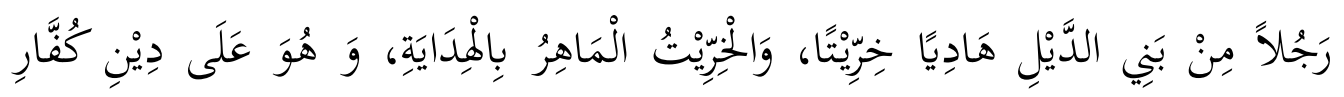

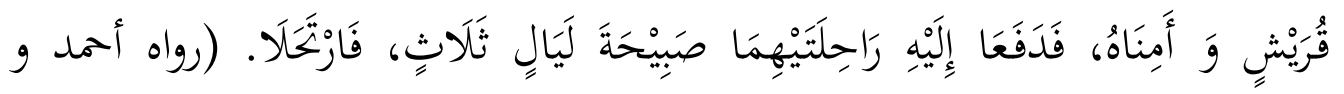

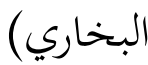
Bakar mengupah seoranglaki-laki dari Bani Diel sebagai petunjuk jalan yang mahir, sedangkan si laki-laki tersebut ketika itu masih berada dalam kelompok agamanya orangorang kafir Quraisy. Nabi dan $\quad$ Abu Bakar mengamanatkan kepada laki-laki tersebut, lalu menyerahkan kedua kendaraan mereka kepadanya, dan mereka menjanjikannya untuk bertemu di gua Tsaur sesudah tiga malam. Si lakilaki itu kemudian datang kepada mereka dengan membawa kedua kendaraan tersebut di pagi hari pada malam yang ketiga itu, lalu

\section{SIMPULAN}

Berdasarkan pembahasanpembahasan di atas, pemakalah ingin menarik beberapa simpulan, di antaranya:

1. Terdapat tiga macam akad yang terjadi pada layanan go-food dalam aplikasi go-jek, yaitu akad sewa menyewa, akad jual beli, dan akad wakalah.

2. Secara umum, transaksi yang ada pada layanan go-food dalam aplikasi go-jek, hingga saat ini sudah sesuai dengan apa yang ditentukan dalam syariat, sudah sesuai rukun dan syaratnya, hingga adanya sukarela dari masing-masing pihak. 
DAFTAR PUSTAKA

Arifin, Zainul. 2012, Dasar-dasar Manajemen Bank Syariah, Jakarta: Pustaka Alfabet.

Aziz, Faishal bin Abdul, 1993, Terjemahan Nailul Author (terjemahan oleh A. Qadir Hassan dkk), jilid 4, Surabaya, PT Bina Ilmu.

Bakar, Taqiyuddin Abu, 2001, Kifayatu alAkhyar fi Halli Ghayat al-ikhtishar fi al-Fiqh asy-Syafi'i, Damaskus: Dar al-Basyair.

Dahlan, Abdul Aziz, dkk, 2001, Ensiklopedi Hukum Islam, Jakarta: Ichtiar Baru Van Hoeve.

Djuwaini, Dimyaudin, 2008, Pengantar Fiqh Muamalah, Yogyakarta: Pustaka Pelajar.

Duwaisy, Ahmad bin Abdurrazzaq ad-, Fatwa-fatwa Jual Beli, Jakarta: Pustaka Imam asy-Syafi'i.

Haroen, Hasrun, Fiqh Muamalah, Jakarta: Gaya Media Pratama.

https://www.go-jek.com/about/, diakses pada 7 Januari 2018 jam 16.30 WIB. Munawwir, Ahmad Warson, 1997, Kamus al-Munawwir Arab-Indonesia lengkap, Surabaya: Pustaka Progresif.

Rachmawati, Eka Nuraini, dan Ghani, Ab Mumin bin Ab, 2015, Akad Jual Beli dalam Perspektif Fikih dan Praktiknya di Pasar Modal Indonesia, Jurnal al-'Adalah, Vol. 12 (4), hal. 785-806.

Sabiq, Sayyid, 1995, Fikih Sunnah Juz. 3. , Beirut: Darul Fikri.

Schacht, Joseph, 2003, Pengantar Hukum Islam, Yogyakarta: Islamika.

Shobirin, Jual Beli dalam Pandangan Islam, Jurnal Bisnis dan Manajemen Islam, Vol. 3 (2), 2015, hal. 240-261. Shomad, Abd., 2017, Hukum Islam: Penormaan Prinsip Syariah dalam Hukum Indonesia, Bandung: Kencana.

Siswadi, Jual Beli dalam Perspektif Islam, Jurnal Ummul Qura, Vol. 3 (2), hal. $59-65$.

Suhendi, Hendi, Fiqh Muamalah, Jakarta: PT. Raja Grafindo Persada.

Zainuddin, Ahmad, 2004, Fathu al-Mu'in, Beirut: Dar Ibn Hazm. 